2. Ali A, Fardy M J, Patton D W. Maxillectomyto reconstruct or obturate? Results of a UK survey of oral and maxillofacial surgeons. Br J Oral Maxillofac Surg 1995; 33: 207-210.

3. Alani A, Bishop K, Renton T, Djemal S. Update on guidelines for selecting appropriate patients to receive treatment with dental implants: priorities for the NHSthe position after 15 years. Br Dent J 2014; 217: 189-190.

4. Schmitt A, Zarb G A. The longitudinal clinical effectiveness of osseointegrated dental implants for single-tooth replacement. Int J Prosthodont 1993; 6 : 197-202.

5. Lindh T, Gunne J, Tillberg A, Molin M. A meta-analysis of implants in partial edentulism. Clin Oral Implants Res 1998; 9: 80-90.

6. Chan M F, Howell R A, Cawood J I. Prosthetic rehabilitation of the atrophic maxilla using pre-implant surgery and endosseous implants. Br Dent J 1996; 181: $51-58$

7. Chan M F, Johnston C, Howell R A, Cawood JI. Prosthetic management of the atrophic mandible using endosseous implants and overdentures: a six year review. Br Dent J 1995; 179: 329-337.

8. Zarb G A, Schmitt A. Osseointegration and the edentulous predicament. The 10yearold Toronto study. Br Dent J 1991; 170: 439-444.

9. Bouchard $P$, Renouard F, Bourgeois D, Fromentin $O$ Jeanneret $\mathrm{M} \mathrm{H}$, Beresniak A. Cost-effectiveness modeling of dental implant vs. bridge. Clin Oral Implants Res 2009; 20: $583-587$.

10. Yap A K, Klineberg I. Dental implants in patients with ectodermal dysplasia and tooth agenesis: a critical review of the literature. Int J Prosthodont 2009; 22: 268-276.

11. Arcuri M R, LaVelle W E, Higuchi K W, Svec B R. Implantsupported prostheses for treatment of adults with cleft palate. J Prosthet Dent 1994: 71: 375-378.

12. Schwartz-Arad D, Levin L. Post-traumatic use of dental implants to rehabilitate anterior maxillary teeth. Dent Traumatol 2004; 20: 344-347.

13. Marx R E, Morales M J. The use of implants in the reconstruction of oral cancer patients. Dent Clin North Am 1998; 42: 177-202.

14. Franzen L, Rosenquist J B, Rosenquist K I, Gustafsson I. Oral implant rehabilitation of patients with oral malignancies treated with radiotherapy and surgery without adjunctive hyperbaric oxygen. Int J Oral Maxillofac Implants 1995; 10: 183-187.

15. Parel S M, Branemark P I, Jansson T. Osseointegration in maxillofacial prosthetics. Part I: Intraoral applications. J Prosthet Dent 1986; 55: 490-494.
16. Weischer T, Schettler D, Mohr C. Concept of surgical and implant-supported prostheses in the rehabilitation of patients with oral cancer. Int J Oral Maxillofac Implants 1996; 11: 775-781.

17. Adell R, Eriksson B, Lekholm U, Branemark PI, Jemt T. Long-term follow-up study of osseointegrated implants in the treatment of totally edentulous jaws. Int J Oral Maxillofac Implants 1990; 5: 347-359.

18. Arvidson $K$, Bystedt $H$, Frykholm A, von Konow $L$, Lothigius E. A 3year clinical study of Astra dental implants in the treatment of edentulous mandibles. Int J Oral Maxillofac Implants 1992; 7: 321-329.

19. Jemt T, Chai J, Harnett J et al. A 5year prospective multicentre follow-up report on overdentures supported by osseointegrated implants. Int J Oral Maxillofac Implants 1996; 11: 291-298.

20. Mericske-Stern R, Zarb G A. Overdentures: an alternative implant methodology for edentulous patients. Int J Prosthodont 1993; 6: 203-208.

21. Awad M A, Lund J P, Shapiro S H et al. Oral health status and treatment satisfaction with mandibular implant overdentures and conventional dentures: a randomized clinical trial in a senior population. Int J Prosthodont 2003: 16: 390-396.

22. Cune M S, de Putter C, Hoogstraten J. Treatment outcome with implant-retained overdentures: Part IIPatient satisfaction and predictability of subjective treatment outcome. J Prosthet Dent 1994; 72: 152-158.

23. Emami E, Heydecke G, Rompre P H, de Grandmont $P$, Feine J S. Impact of implant support for mandibular dentures on satisfaction, oral and general health-related quality of life: a meta-analysis of randomized-controlled trials. Clin Oral Implants Res 2009; 20: 533-544.

24. Hobkirk J A, Abdel-Latif H H, Howlett J, Welfare R Moles D R. Prosthetic treatment time and satisfaction of edentulous patients treated with conventional or implant-stabilized complete mandibular dentures: a case-control study (part 2). Int J Prosthodont 2009; 22. 13-19.

25. Heydecke G, Penrod J R, Takanashi Y, Lund J P, Feine I $S$, Thomason J M. Cost-effectiveness of mandibular two-implant overdentures and conventional dentures in the edentulous elderly. J Dent Res 2005; 84: 794-799.

26. Feine J S, Carlsson G E, Awad M A et al. The McGill consensus statement on overdentures. Mandibular twoimplant overdentures as first choice standard of care fo edentulous patients. Montreal, Quebec, May 24-25: 2002. Int J Oral Maxillofac Implants 2002; 17: 601-602.

27. Thomason J M, Feine J, Exley C et al. Mandibular two implant-supported overdentures as the first choice standard of care for edentulous patientsthe York Consensus Statement. Br Dent J 2009; 207: 185-186.
28. Burns B, Grieg V, Bissell V, Savarrio L. A review of implant provision for hypodontia patients within a Scottish referral centre. Br Dent J 2017; 223: 96-99.

29. Bergendal B, Bergendal T, Hallonsten A L, Koch G, Kurol J, Kvint S. A multidisciplinary approach to oral rehabilitation with osseointegrated implants in children and adolescents with multiple aplasia. Eur J Orthod 1996; 18: 119-129.

30. Epstein NE. Multidisciplinary in-hospital teams improve patient outcomes: A review. Surg Neurol Int 2014; 5(Suppl 7): S295-303.

31. Butterworth C J, Baxter A M, Shaw M J, Bradnock $G$. The provision of dental implants in the National Health Service Hospital dental servicesa national questionnaire. Br Dent J 2001; 190: 93-96.

32. Calvert G, Barclay S C, Owens J S, Alani A. A national survey of restorative consultants' treatment provision for head and neck oncology patients. Br Dent J 2014; 217: E21.

33. Dewan K, Kelly R D, Bardsley P. A national survey of consultants, specialists and specialist registrars in restorative dentistry for the assessment and treatment planning of oral cancer patients. Br Dent J 2014; 216: E27.

34. Becker C M, Kaiser D A. Surgical guide for dental implant placement. J Prosthet Dent 2000; 83: 248-251.

35. Flugge T V, Nelson K, Schmelzeisen R, Metzger M C Three-dimensional plotting and printing of an implant drilling guide: simplifying guided implant surgery. J Oral Maxillofac Surg 2013; 71: 1340-1346.

36. Hebel K S, Gaijar R C. Cement-retained versus screw-retained implant restorations: achieving optimal occlusion and esthetics in implant dentistry. J Prosthet Dent 1997: 77: 28-35.

37. Michalakis K X, Hirayama H, Garefis P D. Cementretained versus screw-retained implant restorations: a critical review. Int J Oral Maxillofac Implants 2003; 18: 719-728.

38. Brånemark P. Surgery and fixture installation. Zygomaticus Fixture Clinical Procedures Göteborg, Sweden: Nobel Biocare. 1998

39. Pi Urgell J, Revilla Gutierrez V, Gay Escoda C G Rehabilitation of atrophic maxilla: a review of 101 zygomatic implants. Med Oral Patol Oral Cir Bucal 2008; 13: E363-370.

40. Tamura H, Sasaki K, Watahiki R. Primary insertion of implants in the zygomatic bone following subtotal maxillectomy. Bull Tokyo Dent Coll 2000; 41: 21-24

41. Weischer T, Mohr C. Ten-year experience in oral implant rehabilitation of cancer patients: treatment concept and proposed criteria for success. Int J Oral Maxillofac Implants 1999; 14: 521-528.

\title{
Correction to: The 'lifespan' of mandibular repositioning appliances
}

The original article can be found online at https://doi.org/10.1038/s41415-019-0730-8.

Author's correction note:

Clinical article Br Dent J 2019; 227: 470-473.

When this article was initially published, the image credit was omitted from the Figure 2 caption. The caption should have read:

“Herbst' style MRA: image @ SCHEU-DENTAL gmbh'

The authors apologise for any confusion caused by this error. 